\title{
Teaching and Learning Chemistry with a Motivating Tool: one CLICK!
}

\author{
R. García-Lopera ${ }^{1}$ \\ ${ }^{1}$ Department of Physical Chemistry, University of Valencia \\ Dr. Moliner, 50 (Burjassot, E-46100, Spain) \\ Corresponding author's email address: rosa.garcia [AT] uv.es
}

\begin{abstract}
The use of electronic response systems or "clickers" is a popular way to engage students and create an active-learning environment, especially within large courses of general subjects for first-year undergraduates. The present work examines with detail the methodology, the tasks and the results obtained respect to the students' learning, participation, and engagement in the classroom. In general, students perceived that, clickers provided a significant enhancement to their learning, and teachers obtained real-time feed-back of how the concepts are assimilated or not by the students in order to quickly introduce improvements in their teaching.
\end{abstract}

Keywords - clickers, electronic voting systems, motivation, active learning

\section{INTRODUCTION}

In recent decades there has been a profound change in the development and dissemination of knowledge, causing its fragmentation and an increase in training needs. This change has been produced as a consequence, among others: of the continuous scientific-technological advances; of the evolution of social behaviour patterns; of the processes of economic and cultural globalization; of the changes in the business organization focused on quality; of the incidence of new information technologies and the emergence of social networks, and of global projects for the creation and dissemination of knowledge (such as Creative Commons, GNU / Linux Project, Open Directory or Wikipedia). These facts have important implications for the University, which has been forced to address reforms and substantive innovations of its objectives, social role and methodologies. As a social institution, the University has always been able to adapt to the various political and cultural changes, without diminishing its relevance as a centre for the development and dissemination of culture and knowledge. In addition, the governments of many countries have become aware of the need to innovate and renew higher education as a means of advancing on the world development. The European Higher Education Area (EHEA $)^{1}$ is a quality European education system that seeks to promote economic growth in Europe, international competitiveness, mobility and social cohesion, through education and training of citizens throughout life. The impact of the Bologna Process on university education has been profound. In the first place, it has demanded the change of mentality from a knowledge-centered teaching to one focused on competences, a question that teachers must consider when planning their teaching. On the other hand, teachers are impelled to a thorough review of their teaching to establish the workload of the student and the appropriate teaching methodologies to achieve the learning objectives and results (Villa, 2004, Bain, 2007 and 2012, Rué, 2007, Zabalza, 2010). As explained by Gros and Romaña (2004), "the teaching profession of the 21 st century will have little to do with the image of a teacher on the stage and teaching his class in front of a group of students". Professors must improve not only cognitive learning but also the acquisition of other skills that are considered equally important for the training of students as future professionals (Sanz, 2017). The training, in this professional challenge, is a key element for success.

Consequently, "we cannot continue teaching the future generations with the tools that were part of our past".

The key concept in this whole process has been innovation. Innovation is fashionable in almost all areas of society and is equated with meanings such as improvement, evolution, quality, progress or development. The problem lies in clearly specifying what innovation consists of inside the process of improving teaching in the university system. In this sense, it is essential to take care of the training of students in both personal and professional competences, since the mere acquisition of knowledge is no longer enough. Current teaching of any discipline must assume these new needs and has to make great improvements in teaching practices. Among the methods to achieve these improvements are the assessment

${ }^{1}$ http://ec.europa.eu/education/policy/higher-education/bologna-process_es 
of the student's personal work, non-presential activities (on-line) and the loss of prominence of the master class.

Modern teaching can only be developed through the use of all the possibilities offered by the Internet and the new information and communication technologies, ICTs (Valero and Navarro, 2008, Martínez Tomás et al., 2011). Specially, nowadays with the Covid-19 pandemic time, the need to change the secondary and high school ways of teaching to a hybrid model (presential and online) is more necessary than ever before (Holme, 2020).

For all these reasons, from the academic year 2003-04 to 2009-10 and before the implementation of the current Degrees in Spain (course 2010-11), the Faculty of Chemistry of the Universitat de València carried out a Pilot Project of Educational Innovation. Its main challenge was to adapt the teaching-learning methodologies to the recommendations and needs of the EHEA. To do so, a profound change was needed in the teaching model, now focused on the work and learning of the students and in the promotion and development of competences that would enable them to continue learning throughout their lives (the so-called "long life learning" or L3).

To achieve this challenge, many innovative teaching activities and methodologies were developed such as: minisymposiums with invited papers, oral communications and posters; reading workshops; cooperative interdisciplinary work; visits to companies and museums accompanied by a dossier of work; use of portfolios; on-line questionnaires; use of e-learning platforms; viewing videos for lab practices; thematic channels on youtube; forums and discussion chats in class; etc. (Pou Amérigo, 2004, Pou and Ochando, 2007, García-Lopera et al., 2007, 2008 and 2011). Moreover, our teacher's team also acquired an electronic voting equipment (also known as "clickers") that we found interesting to incorporate, punctually, during the lectures to increase attention, participation and motivation.

These systems are a very popular tool that facilitate student participation using interactive exercises in the classroom designed to assess the student's understanding of a particular topic. In addition to increasing motivation and participation, they also provide many additional pedagogical benefits as they include the instantaneous response both for students (Sancerni, 2015) and for teachers (Skinner, 2009, Gibbons et al., 2017, Niemeyer et al., 2018). For some years, the use of this tool supposes a support to the master classes and has been used in different ways and in very different academic contexts (Remón et al., 2014, García-Lopera, 2013, 2015 and 2017). It also promotes opportunities for collaboration or peer instruction (individual or group) which is another very interesting and participating strategy in the classroom (Smith, 2009). Summarizing, the use of clickers can facilitate the improvement of skills as fundamental as the resolution of problems of any kind (Levesque, 2011).

The effect of using the clicker system on student learning has been evaluated in a wide variety of disciplines within the sciences, particularly in chemistry (MacArthur et al., 2008 and 2013), in physics (Reay et al., 2008; Deslauriers et al., 2011), in earth sciences (Zimmerman, 2006); in flipped teaching in a Plant Physiology Course (Sanz, 2017) and in very specific subjects such as laboratories (Sevian et al., 2011).

Very recently, this technology has also been used in peer instruction method working in team-based clicker model (Pearson, 2019). The model involved three to five students per team and led to better student exam performance and improved student retention while also generating more favorable student survey data when compared against individual clicker-handset usage (Pearson, 2017).

As said before, the covid-19 lockdown forced most universities to transition from their normal face-to face to a remote online learning. Around the world, students are having to work from home, and the chemistry education community has been forced to adapt to the new circumstances and to ensure pedagogical continuity in order to provide its students with the knowledge necessary for their success. A lot of experiences have been compiled in an special issue of Journal of Chemical Education published in September 2020: "Insights Gained While Teaching Chemistry in the Time of COVID-19" (Worrall et al.; Danjou; Gray, Schweiker and Levonis, Jie Ang, 2020).

\section{OBJECTIVES AND COMPETENCES}

The fundamental objective of our proposal was to do something different during the face-to-face classes that could be motivating for the current student type (millennials and $\mathrm{Z}$ generation are very digital). So, the specific goals to achieved were: i) attract their attention and break the routine of the master lectures of theory; ii) involve students and increase their participation; iii) in a certain way, allow to have fun, without losing academic rigor; and iv) finally, incorporate the use of information and communication technologies (ICTs).

We also intended or pursued the student to prepare, autonomously, the laboratory experiences prior to his attendance at the practical session. To do that, we have implemented the realization with the "clickers" of a questionnaire as soon as we arrived at the lab session.

Another of the important objectives was to be able to obtain feedback of the educational process, both for the teachers: what concepts have not been clarified? what conceptual errors still persist? in what aspects should be deepened? etc.... and for the students, since it allows them to know how their learning process progresses. 
With all this in mind, in order to work and consolidate chemical concepts taught in class and in the laboratory, and at the same time promote teamwork, we have proposed the use of "remote controls" (clickers or zappers, in Anglo-Saxon nomenclature). The activity aims to develop, among others, five fundamental basic competences; four transversal competences and, at least, six specific competences (detailed in Table 1).

Table 1: Competences to be promoted with the use of electronic voting systems.

\begin{tabular}{l|l|l}
\hline Basic and General & \multicolumn{1}{|c}{ Transversal } & \multicolumn{1}{c}{ Specific } \\
\hline $\begin{array}{l}\text { Inductive and deductive } \\
\text { capacity }\end{array}$ & $\begin{array}{l}\text { Basic skills in information } \\
\text { and communication } \\
\text { technologies }\end{array}$ & $\begin{array}{l}\text { Demonstrate knowledge and understanding of } \\
\text { facts, concepts, principles and theories related to } \\
\text { the areas of Chemistry }\end{array}$ \\
\hline $\begin{array}{l}\text { Effective resolution of } \\
\text { problems }\end{array}$ & $\begin{array}{l}\text { Ability to manage } \\
\text { information }\end{array}$ & Solve qualitative and quantitative problems \\
\hline Decision making & Auto-evaluation of learning & $\begin{array}{l}\text { Evaluate, interpret and synthesize data and } \\
\text { information }\end{array}$ \\
\hline Autonomous learning & Teamwork & $\begin{array}{l}\text { Carry out standard experimental procedures } \\
\text { Critical thinking }\end{array}$ \\
\hline & $\begin{array}{l}\text { Interpret data from observations and measurements } \\
\text { in the laboratory according to their significance and } \\
\text { the theories that support them }\end{array}$ \\
\hline & $\begin{array}{l}\text { Assess the risks in the use of chemical substances } \\
\text { and laboratory procedures }\end{array}$ \\
\hline
\end{tabular}

\section{METHODOLOGY}

For the design of any material, strategy, task or significant learning exercise, we must start from a premise, in the words of teachers Valero and Navarro (2008): to prepare teaching activities that the student cannot "escape" without having learned.

Therefore, in class we make three types of approaches, depending on the type of activity: (1) consolidation of concepts in daily classroom; (2) previous study and preparation of laboratory sessions; or (3) to maintain attention and participation. In the first two cases, the qualification obtained is taken into account in the section "continuous assessment" of the different subjects where it is applied and is previously communicated to the students in the Teaching Guide.

\subsection{At Classroom}

In the first case, students are offered a questionnaire to work on theoretical concepts and/or small numerical exercises in PowerPoint format. If the class group is very large, as is usual in the first years of the Chemistry Degree and in basic subjects, we work in small groups to encourage collaborative teamwork and peer instruction.

The questionnaire is distributed, first on paper to be worked on and discussed in groups of 4-5 students, and when the time required for the activity ends, it is evaluated at the moment by answering with the remote control. To do this, the questions are projected, and the collection time of the answers issued and administered by the manager/professor. The answers to each question are collected and stored in the computer through a voting unit code that has been assigned to a student or a group. In the end, the results obtained are projected in real time. In this way, the teacher can discuss them, fix errors or misconceptions, insist and deepen the most weakly learned concepts, etc ... This activity is carried out punctually, in those most important topics and that require knowledge to be well established. A real example of its use in class can be seen in Figure 1.

\subsection{At Laboratory}

In the second case, upon arriving at the laboratory, the students perform (individually) a questionnaire about the previous tasks carried out at home (viewing videos, reading the script, consulting materials available on the virtual platform, ...). The objective is to arrive at the laboratory with the appropriate knowledge of what is going to be done, why and how. This work is evaluated by the voting team software and incorporated into the student's continuous assessment. This activity is carried out at the beginning of each laboratory session, in order to correct all the inaccuracies, errors or doubts that the student may have before carrying out the experimental work. Note that the laboratory work of a chemist must be very rigorous and not be left to chance, to the trial and error, because the products used are expensive and 
potentially toxic and contaminants. An example of the type of questions asked before a laboratory session can be seen in Figure 2. The answers obtained to each question are also presented in percentages, together with the correct solution, which allows, as we have already said, to analyze and correct in situ the concepts not assimilated.

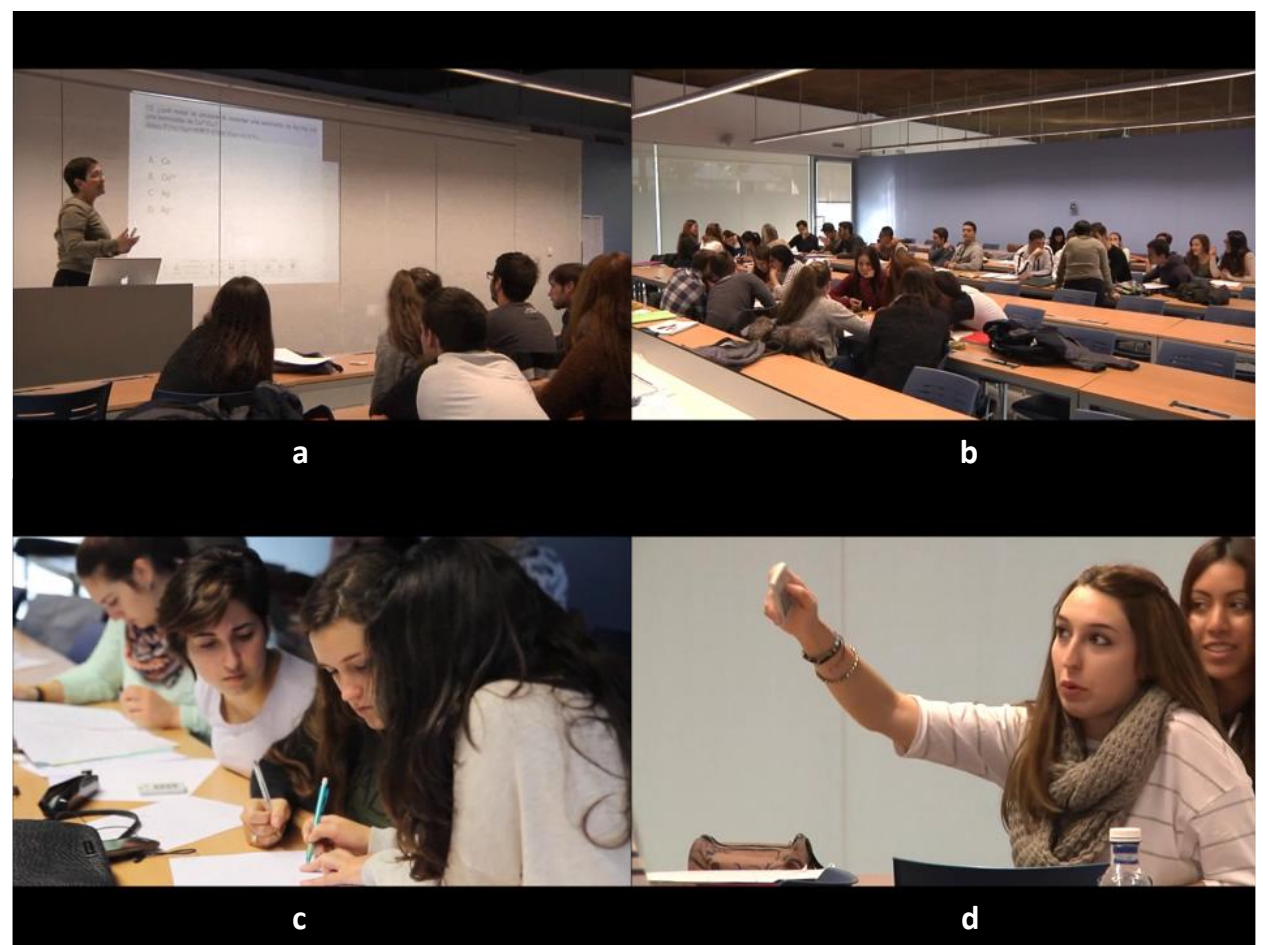

Figure 1: Work in the Classroom using Electronic Voting Systems: (a) Projection of the Question to be Solved, (b and c) Work in Small Groups for Solution, and (d) Sending Responses for Evaluation and Feedback.

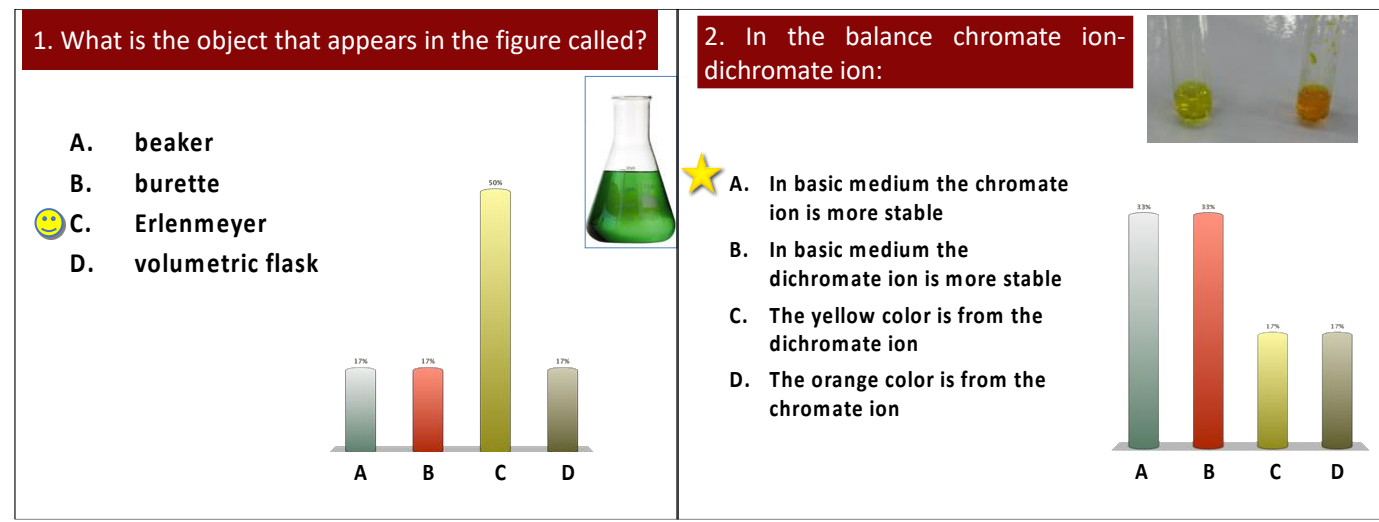

Figure 2: Examples of Questions from the Questionnaire prior to a Laboratory Session, together with the Percentage of Correct and Incorrect Answers.

\subsection{In Non-evaluable activities}

Thirdly, we have also used this teaching methodology, although without evaluative purposes, to maintain attention and participation during master lectures. While the teacher makes the explanations, introduces from time to time, test questions about the explained, and asks the student to respond with the command; similar to the way the learning platform based on the game Kahoot works. ${ }^{2}$

\footnotetext{
${ }^{2}$ https://kahoot.it
} 


\section{EQUIPMENT}

To carry out teaching activities in class with this methodology, it is necessary to have:

- software (programs or applications). In our case, we opted for a Turning Technologies ${ }^{\circledR}$ equipment ${ }^{3}$ (https://www.turningtechnologies.com).

- a signal receiver

- remote controls

- teaching material, which is the key, because without this material the equipment would not be sufficient.

The software is basically complemented with the PowerPoint app to prepare the questionnaires and Excel applications to show the results which are offered in a wide variety of reports and statistics that allow teachers to analyze them, by question, by student, by group, global, etc ... (see Figure 3).

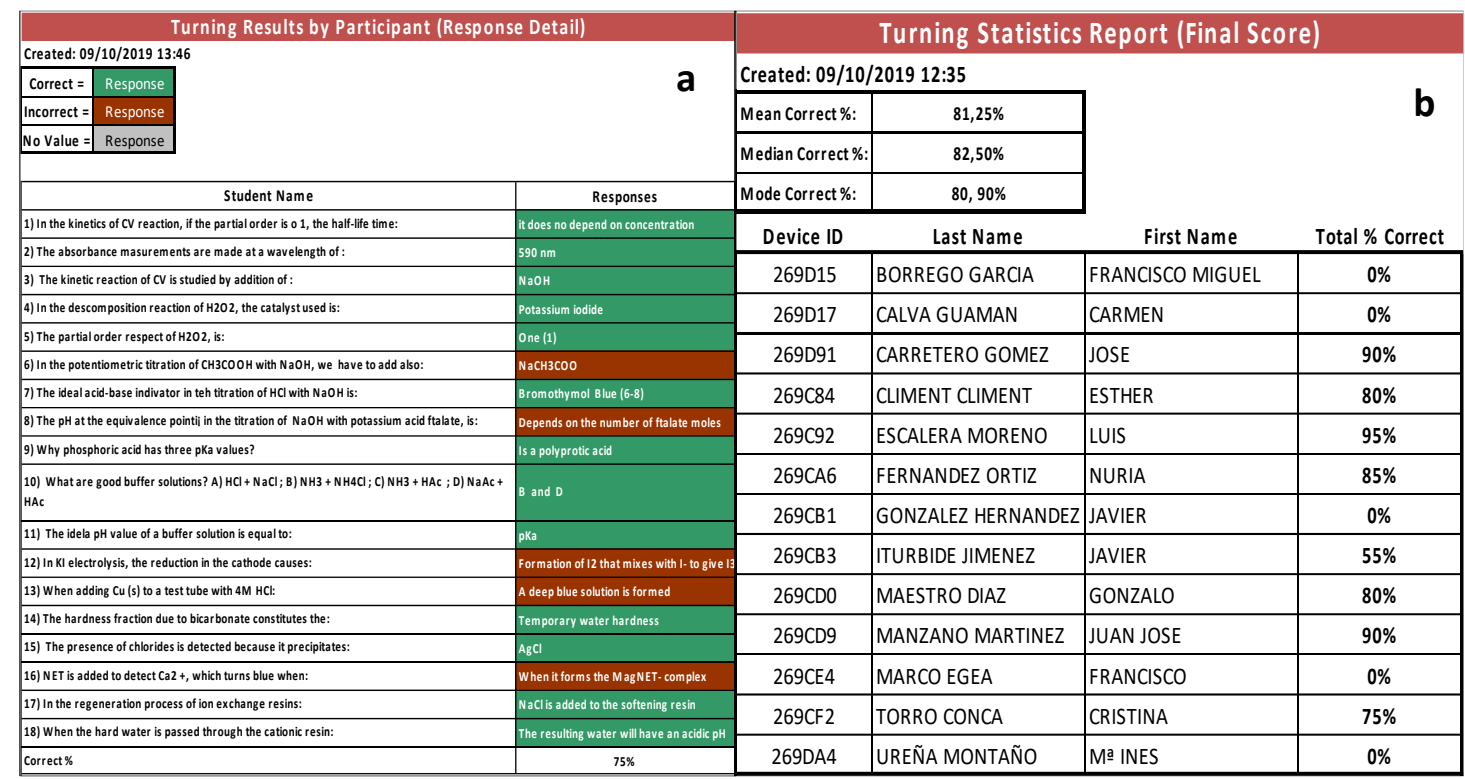

Figure 3: Different Types of Reports Obtained after the Clicker Session/Questionnaire: (a) Individual Student Report, with the Results of each Question and (b) Global Report, for the Whole Group.

Finally, we would like to comment that, currently, mobile devices (smartphones and/or tablets) also allow being used as remote controls, either through non-free mobile applications (paying for the corresponding licenses) or free ones, such as Socrative (Puche Gil, 2017).

\section{ASSESSMENT}

Any initiative or activity aimed at obtaining objectives does not make sense without a subsequent analysis regarding the achievement of the same. Therefore, it is interesting to make a reflection on the part of the participating teachers and the opinions expressed by the protagonists, the students.

Although quantitative tools and statistics have not been used to assess the degree of achievement of the objectives, we have collected some evidence that show how the activity has allowed a significant progress in the acquisition of the aforementioned skills. It is clear that its full development is an objective of the degree, and in no case can be expected to achieve it in a single course. However, we have corroborated an undoubted progress, given that they are first-year students and that this is their first experience of this type.

Since we began the use of this methodology, in the 2003-04 academic year, we have collected the opinion of the students through an anonymous survey Likert type in which they value from 1 (little) to 5 (a lot) the usefulness of the electronic voting system in their learning and participation, as well as other different methodologies and tools used in

\footnotetext{
${ }^{3}$ https://www.turningtechnologies.com
} 
class. Table 2 shows the results obtained in the surveys for the last eight years in which the Degree in Chemistry is implemented.

Table 2: Results of the surveys carried out in different academic courses for students in the first year of the Degree in Chemistry related to the usefulness of the use of clickers in their learning (Likert type responses: 1 means non useful and 5 extremely useful).

\begin{tabular}{l|c|c|c|c|c|c|c}
\hline Year & $\mathbf{n}^{\mathbf{0}}$ surveys & $\mathbf{1}$ & $\mathbf{2}$ & $\mathbf{3}$ & $\mathbf{4}$ & $\mathbf{5}$ & $\begin{array}{c}\text { Weighted } \\
\text { average rating }\end{array}$ \\
\hline $2010-11$ & 58 & 1 & 2 & 2 & 10 & 43 & 4,59 \\
$2011-12$ & 63 & 2 & 2 & 4 & 14 & 41 & 4,43 \\
$2012-13$ & 60 & 1 & 2 & 2 & 15 & 40 & 4,52 \\
$2013-14$ & 59 & 0 & 1 & 1 & 12 & 45 & 4,71 \\
$2014-15$ & 68 & 1 & 2 & 2 & 15 & 48 & 4,57 \\
$2015-16$ & 80 & 2 & 3 & 2 & 18 & 55 & 4,51 \\
$2016-17$ & 82 & 1 & 4 & 3 & 20 & 54 & 4,49 \\
$2017-18$ & 79 & 1 & 2 & 2 & 16 & 58 & 4,62 \\
\hline
\end{tabular}

As can be seen in Table 2 and Figure 4, course after course, most of students have a good opinion of this methodology and find it very useful and motivating.

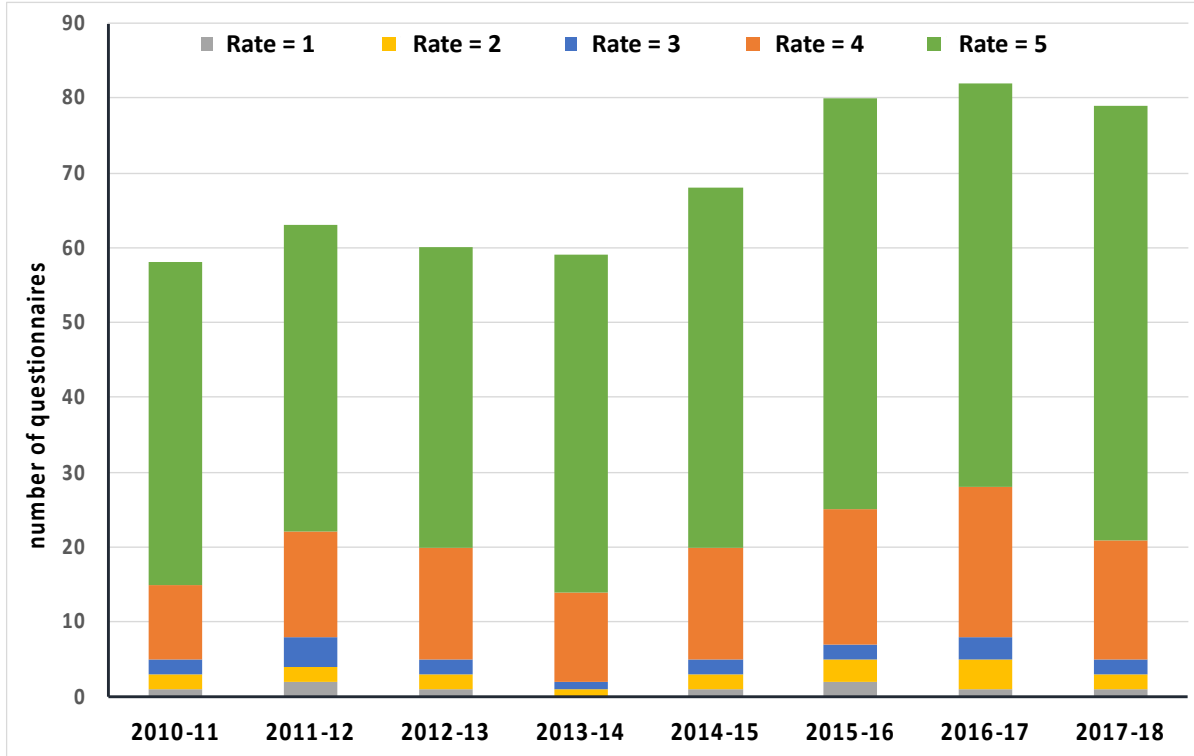

Figure 4: Assesments made by Students of First Year Chemistry Degree about the Usefulness of Using Clickers in Daily Master Class for Learning (from 1 to 5).

In addition to the quantitative result, we would like to write down some of the opinions freely expressed by the students in the "observations" section of the survey:

- "we have learned chemistry in a more pleasant way",

- "it helps us to learn to investigate about things autonomously, on our own" 
- "I had a great time working with my colleagues"

- "I think it clearly fits one of the competences pursued in the educational innovation project"

- "the student must not only be taught to work in a group, but a teacher also has to promote him to work on his own, to stand on his own, to survive"

- "it's been a lot of fun",

- "I would be delighted if more teachers carried out this kind of activities in class"

Regarding the teacher's viewpoint, the survey completed by those that have implemented the tool, reflects that: the activity allows to get "feed-back" fast (in real time) and continuous on the learning of our students; allows to detect immediately those aspects of the subject that have not been clear, and, therefore, correct the development of the lessons/classes without waiting for the completion of term and exams at the end of the academic year. Moreover, it helps in the continuous evaluation of the students to inform them of their progress throughout the course. From the point of view of the workload, it saves the teacher time since the program automatically corrects the questionnaire.

However, it is worth adding that we must be prudent in the use of these devices because, if it used continuously, the distraction generated may exceed the objectives to be achieved. Realistically, there are a number of difficulties that cannot be avoided. One of the most striking is that the realization of these projects consumes class time, and the current curricula of the Spanish Universities are time constrained.

Finally, also other authors conclude in their assessments, that the use of electronic response pads or "clickers" is a popular way to engage students and create an active-learning environment, especially within large chemistry courses. They also examined students' perceptions of how the clicker affected their learning, participation, and engagement in the classroom, as well as their overall experience within a first-semester general chemistry course. Overall, students perceived that, clickers provided a significant enhancement to their learning, with women valuing the technology to a greater extent (Niemeyer and Zewail-Foote, 2018; López-Rodríguez and Barac, 2019).

\section{CONCLUSIONS AND IMPLICATIONS FOR TEACHING}

After more than a decade developing educational innovation projects in the first year of the Degree of Chemistry, the accumulated experience tells us that any active learning strategy is very useful to encourage student involvement and to get the student to relate to each other contents seen in the subject, achieving in this way a significant and integrating learning. In addition, the use of methodologies related to new technologies, favors very clearly the development of a good number of generic and specific competences.

We have also verified that the marks obtained by the students with the electronic response system correlate directly with those obtained in the exams. Moreover, active and meaningful learning results in an improvement in test scores and a decrease in failure, in line with what has been observed by other authors (Graham et al., 2013).

It is a fact that "to get different results you have to do different things", and therefore, we encourage teachers to incorporate this type of activity in their teaching, obviously adapting the format to the level of the course and to each specific subject. We sincerely believe that another education is possible.

\section{ACKNOWLEDGEMENT}

The author would like to acknowledge the Servei de Formació Permanent and the Vicerectorat of Convergència Europea i Qualitat of the Universitat de València for funding this work through different projects: UV-SFPIE-DOCE1280854 and UV-SFPIE-FO12-80995.

To professors L.E. Ochando and R.Pou, for being part of our excited and tireless teaching team.

And finally, to the authentic protagonists of the teaching-learning process, the students, whose effort and enthusiasm in this teamwork allows us to affirm categorically that it has been very productive.

\section{REFERENCES}

[1] Bain, K., Lo que hacen los mejores profesores universitarios, Publicacions Universitat de València (PUV), Valencia, Spain, 2007. 
[2] Bain, K., What the Best College Students Do, Belknap Press of Harvard University Press, Cambridge, 2012.

[3] Danjou, P-E., "Distance Teaching of Organic Chemistry Tutorials During the COVID-19 Pandemic: Focus on the Use of Videos and Social Media”, Journal of Chemical Education, vol. 97, pp. 3168-3171, 2020.

[4] Deslauriers, L., Schelew, E., Wieman, C., "Improved Learning in a Large-Enrollment Physics Class", Science, vol. 332, pp. 862-864, 2011.

[5] García-Lopera, R., "Motivación en el aula: uso de clickers", In: Actas de la Jornada de Intercambio sobre Estrategias de Enseñanza de las Ciencias. Valencia, Spain, 2013.

http://mmedia.uv.es/buildhtml?user=asamar4\&path=/cream/Jornadas/Ensenanza_Ciencia/\&name=RosaGarciaLopera.mp4

- "Zapeando en clase: ¿es posible aprender y divertirse con un click?", In: Jornada sobre Sistemas de Votación Electrónica en la Docencia Universitaria (JSVE). Valencia, Spain, 2015. http://mmedia.uv.es/html5/g/cream//43060 rosa garcia.mp4

- "Enseñar Química y motivar con un click", Revista Internacional de Aprendizaje en Ciencia, Matemáticas y Tecnología, vol. 4, no. 2, pp.17-25, 2017.

[6] García-Lopera, R., Pou, R., Ochando, L. E., "El mini-simposium como herramienta de aprendizaje activo y colaborativo", In: Actas de la II Reunión INDOQUIM 2007, pp. 127-128, Vigo, 2007. ISBN-13: 978-84-611-7615-1

- "Cóctel de competencias genéricas: taller de lectura + trabajo en equipo en formato mini-simposio", In: Actas de la III Reunión INDOQUIM 2008, Cádiz, 2008. ISBN-13: 978-84-9828-201-7

- "Química en cada mes del año: la elaboración de un calendario como actividad transversal en equipo", In: Actas de la VI Reunión INDOQUIM 2011, Alicante, 2011.

[7] Gibbons, R. E., Laga, E. E., Leon, J., Villafañe, S. M., Stains, M., Murphy, K., Raker, J. R., "Chasm Crossed? Clicker Use in Postsecondary Chemistry Education”, Journal of Chemical Education, vol. 94, pp. 549-557, 2017.

[8] Graham, M. J., Frederick, J., Byars-Winston, A., Hunter, A.-B., Handelsman, J., "Increasing Persistence of College Students in STEM", Science, vol. 341, pp. 1455-1456, 2013.

[9] Gray, S.D., "Embedded Video Questions as a Low-Stakes Assignment During the Remote Learning Transition", Journal of Chemical Education, vol. 97, pp. 3172-3175, 2020.

[10] Gros, B., Romaña, T., Ser profesor. Palabras sobre la docencia universitaria, Eds. Octaedro, Barcelona, 2004.

[11] Holme, T.A., "Chemistry Education in Times of Disruption and the Times that Lie Beyond", Journal of Chemical Education, vol. 97, pp. 1219-1220, 2020.

[12] Jie Ang, J.W., "Scaffolded Inverse Blended Learning: An Approach to Teach an Online General Chemistry Course", Journal of Chemical Education, vol. 97, pp. 2839-2844, 2020.

[13]Levesque, A. A., "Using Clickers to Facilitate Development of Problem-Solving Skills", CBE Life Science Education, vol. 10, pp. 406-417, 2011.

[14]López-Rodríguez, M. I., Barac, M., "Valoración del alumnado sobre el uso de Clickers y vídeo tutoriales en educación superior”, Research in Education and Learning Innovation Archives (Realia), vol. 22, pp. 29-44, 2019.

[15] MacArthur, J. R., Jones, L. L., "A Review of Literature Reports of Clickers Applicable to College Chemistry Classrooms", Chemistry Education and Research Practice, vol. 9, pp. 187-195, 2008.

- "Self-Assembled Student Interactions in Undergraduate General Chemistry Clicker Classrooms", Journal of Chemical Education, vol. 90, pp. 1586-1589, 2013.

[16] Martínez Tomás, M.C. et al., "La evaluación y seguimiento del estudiante de forma telemática: el proyecto cuestionarios", @ tic Revista de Innovación Educativa, vol. 6, pp. 91-95, 2011.

[17] Niemeyer, E. D., Zewail-Foote, M., "Investigating the Influence of Gender on Student Perceptions of the Clicker in a Small Undergraduate General Chemistry Course", Journal of Chemical Education, vol. 95, pp. 218-223, 2018.

[18] Ochando Gomez, L.E., Pou Amerigo, R., Actividades de aprendizaje cooperativo en el marco de un proyecto de innovación educativa en la Facultad de Química de la Universitat de València, In "Aprendizaje activo de la Física y la Química", Ed. G. Pinto, Madrid, pp. 175-182, 2007.

[19] Pearson, R. J., "Tailoring Clicker Technology to Problem-Based Learning: What's the Best Approach?”, Journal of Chemical Education, vol. 94, pp. 1866-1872, 2017.

- "Exploring Peer Instruction: Should Cohort Clicker Responses Appear During or After Polling?", Journal of Chemical Education, vol. 96, pp. 873-879, 2019.

[20] Pou Amérigo, R., "Innovación Educativa en el Marco de la Convergencia Europea: Una Experiencia Piloto en Química", Revista de la Red Estatal de Docencia Universitaria, vol. 4, pp. 47-59, 2004.

[21]Pou-Amerigo, R., Ochando Gomez, L.E., Serrano-Andres, L., "Teaching Innovation in the Framework of the European Higher Education Area: an ECTS Experience in Chemistry”, In: Proceedings of INTED2007, Valencia, 2007. ISBN: 978-84-611-4517-1

[22]Puche Gil, J., "Aplicaciones innovadoras en el nuevo proceso de enseñanza-aprendizaje universitario: Remind y Socrative”, In: VII Congreso Internacional de Tecnología, Ciencia y Sociedad, Valencia, España, 2017.

[23] Reay, N., Li, P., Bao, L., "Testing a New Voting Machine Question Methodology", American Journal of Physics, vol. 76, pp. 171-178, 2008. 
[24] Remón J., Sebastián V., Romero E., Arauzo J., "Efecto del uso de nuevos métodos interactivos en la formulación de preguntas en el aula sobre el grado de participación y acierto de los alumnos”, In: II Congreso de Innovación Docente en Ingeniería Química,Valencia, Spain, 2014.

[25] Rué, J., Enseñar en la Universidad: el EEES como Reto para la Educación Superior, Ed. Narcea, Madrid, 2007.

[26] Sancerni Beitia, M.D., “Clickers: una buena práctica de autoevaluación”, In: Jornada sobre Sistemas de Votación Electrónica en la Docencia Universitaria (JSVE), Valencia, Spain, 2015.

[27] Sanz, A. (2017). Innovative Educational Activities Implemented in a Plant Physiology Course following the Bologna Agreement. Proceedings of INTED2017 Conference. Valencia. ISBN: 978-84-617-8491-2

[28] Schweiker, S.S., Stephan M. Levonis, S.M. "Insights Gained While Teaching First Semester Chemistry in the Time of COVID-19 at Bond University in Australia", Journal of Chemical Education, vol. 97, pp. 2863-2865, 2020.

[29] Sevian, H., Robinson, W. E., "Clickers Promote Learning in All Kinds of Classes-Small and Large, Graduate and Undergraduate, Lecture and Lab", Journal of Colloid Science Teaching, vol. 40, pp. 14-18, 2011.

[30] Skinner, S., “On Clickers, Questions, and Learning”, Journal of Colloid Science Teaching, vol. 38, pp. 20-23, 2009. [31] Smith, M. K. et al., "Why peer instruction improves student performance on in-class concepts questions", Science, vol. 323, pp. 122-124, 2009.

[32] Valero García M., Navarro Guerrero, J.J., "Diez metáforas para entender (y explicar) el nuevo modelo docente para el EEES”, @ tic Revista de Innovación Educativa, vol. 1, pp. 3-8, 2008.

[33] Villa, M., Educadores Orientados al Aprendizaje, In: La profesión de profesor de universidad, Michavila, F. and Martínez, J. (eds), Cátedra UNESCO de Gestión Política, pp. 53-60, Madrid, 2004.

[34] Worrall, A.F., Bergstrom Mann, P.E., Young, D., Wormald, M.R., Cahill, S.T., Stewart, M.I., "Benefits of Simulations as Remote Exercises During the COVID-19 Pandemic: An Enzyme Kinetics Case Study", Journal of Chemical Education, vol. 97, pp. 2733-2737, 2020.

[35]Zabalza, M.A., "Ser profesor universitario hoy", La cuestión universitaria, vol. 5, pp. 69-81, 2010.

[36]Zimmerman, A. R., Smith, M. C., "Engaging Today's Students in Earth Science”, Transactions of the American Geophysical Union, vol. 87, pp. 339-344, 2006. 